\section{European \\ Neurology}

Eur Neurol 2009;62:180-187

DOI: $\underline{10.1159 / 000228262}$
Received: May 25, 2009

Accepted: May 25, 2009

Published online: July 11, 2009

\title{
Yawning in Diseases
}

\author{
Olivier Walusinski
}

Brou, France

\section{Key Words}

Yawning $\cdot$ Migraine $\cdot$ Stroke $\cdot$ Tic

\begin{abstract}
Yawning is a physiological behavior, an emotional stereotypy that indicates the homeostatic process of the mechanisms regulating rhythms, such as sleeping/waking, hunger/ satiety or mating/relaxation, generated by the diencephalon. As with all physiological behaviors, its deregulation reveals disorders. In daily practice, yawning as a symptom is generally neglected. That is why we propose a wide overview of yawning in diseases, its consequences and significance.

Copyright $\odot 2009$ S. Karger AG, Base
\end{abstract}

Yawning is a phylogenetically old, stereotyped phenomena that occurs in reptiles, fish, birds and mammals. A yawn is a paroxystic cycle characterized by a standard cascade of movements over a 5- to 10 -second period. The mouth, previously closed, opens widely for 4 to 6 seconds with simultaneous retraction of the tongue, and is usually combined with retroflexion of the head and sometimes elevation of the arms (pandiculation). This movement pattern is often repetitive. Yawning clearly appears to be not just a matter of opening one's mouth, but a generalized stretching of the muscles of the respiratory tract (diaphragm, intercostal), face and neck. Thus, it can be inferred that yawning is a part of the generalized stretch with which it is generally accompanied $[1,2]$.

Yawning and pandiculation are associated with transitions between wakefulness and sleep, occurring at the onset of hunger or satiety and with the ebb and flow of emotional states secondary to living in hierarchical social groups [3]. They exteriorize the activity of the motor centers of the brainstem (V, VII, IX, X, XI, XII) and of the spinal cord under the control of the hypothalamic paraventricular nucleus $(\mathrm{PVN})$. The $\mathrm{PVN}$ is a point of integration between the central and peripheral autonomic systems. Among other things, it plays a role in metabolic balance (osmolarity, energy), blood pressure and heart rate, and sexuality. Yawning and pandiculation can be triggered by injections (apomorphine, hypocretins, etc.) or inhibited after an electrical lesion in the parvocellular zone of the PVN. A group of oxytocin neurons situated in this zone and projecting to the hippocampus, the brainstem (locus ceruleus) and the spinal cord control yawning and erection. The stimulation of these neurons by dopamine or its agonists, such as excitatory amino acids (NMDA), histamine and oxytocin itself, triggers yawning and erection, whereas GABA and opioids have an inhibitory effect $[4,5]$. A specific role for the dopamine D3 receptor in this behavior has yet to be elucidated. Collins et al. [6] report that dopamine D2/D3 agonists elicit dose-dependent yawning behavior in rats, resulting in an inverted U-shaped dose-response curve. The induction of yawning is a D3 receptor-mediated effect, whereas the inhibition of the yawning observed at higher doses is due to competing D2 receptor activity [6].

As with all physiological behaviors, its deregulation reveals disorders that we now present.

Can one talk about the 'disease of yawning'? H. Meige and G. Feindel [7, p. 346] wrote in 1902 in their famous book, Tics and their Treatment (Les tics et leur traitement):

\section{KARGER}

Fax +4161306 1234 E-Mail karger@karger.ch www.karger.com

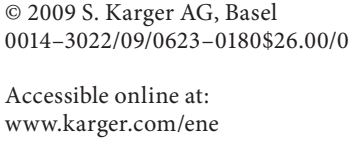

E-Mail walusinski@baillement.com 
Yawning and sneezing, which, like swallowing, are reflexive phenomena whose mechanism is voluntarily modified only with great difficulty, can hardly be perturbed except with respect to their frequency. Saenger (Observations on the idiopathic spasm of the tongue, Monatsschrift für Psychiatrie und Neurologie, January 1900, p. 77) reported on the case of a 29 -year-old woman, who was not hysterical and who presented with episodes of yawning with rigidity in the arms, followed by rapid contractions of the tongue for around a minute. She recovered after several months. The case concerned an 'idiopathic spasm', probably some sort of tic. However, these functional anomalies of yawning or sneezing most often occur in hysterical subjects. It should also be remembered that yawning may be the aura of an epileptic seizure. Uncontrollable yawning is also seen in meningitic incidents, and in cases of tumors of the brain or cerebellum.

The analysis of clinical observations in light of neurophysiological knowledge accumulated over a century allows us to affirm the existence of pathological yawning and to distinguish between its various forms: the dissatisfaction of incomplete yawning, the disappearance of yawning and the excess of repeated yawning.

\section{Anhedonia}

Frustration due to an incomplete or inharmonious development of a yawn is a frequent complaint. Yawning is a stretching of respiratory muscles and muscles of the face, and is sometimes associated with a generalized muscular stretching of the trunk and limbs. The yawner perceives differences in muscle tonus, a veritable and conscious extraction of the progress of the phenomenon, its stimulus and contextual valence, through interoceptive pathways (projections by the lateral spinothalamic tract onto the insular cortex) leading to a hedonistic perception. The dissatisfaction felt seems to be linked to an unconscious inhibition of the 'letting go' that underlies a complete yawn. Therapeutic interventions for anxiety states or for insomnia, such as relaxation or sophrology, use the control of yawning as a means of relaxation or an antistress aid, a veritable proprioceptive rehabilitation of the body scheme $[8,9]$.

\section{The Disappearance of Yawning}

Yawning is a banal action, often barely noticed or felt. It seems that its disappearance is not perceived. Complaints of missing the feeling of well-being associated with yawning, due to the absence of yawning, remain the exception. In daily life, there appears to be no particular consequences of not yawning. The reality of this fact can be questioned, since some yawns could occur without being felt or noticed. Certain extrapyramidal syndromes are accompanied by a disappearance of yawning, such as in the case of treatment with neuroleptics [10] or Parkinson's disease [11]. This disappearance indicates the activity state of the dopaminergic neurons of the PVN of the hypothalamus, which are necessary for yawning. Experimental pharmacology has shown the specificity of the D3 dopamine receptors in triggering this behavior [12]. While the neuroleptics currently in use have no specific target of action, one may assume that the presence or absence of yawning in Parkinson's disease reflects the state of the neuronal population (functional or undergoing degenerative involution). The treatment of episodes of motor blocks in Parkinson's patients by apomorphine hydrochloride, a rapid-action dopaminergic stimulant, triggers yawning, as does treatment with L-DOPA, but in a less systematic fashion [13-15]. Dewey et al. [16] notes this effect in $8 \%$ of the patients treated, and its absence in the case of a placebo injection. Yawning is clearly described by the patients not as discomfort, but as a signal of unblocking, and indicates the beginning of the effect of the relieving treatment [17-20].

\section{Excessive Yawning}

The most common cause of frequent and repeated yawning is sleep debt, particularly in children and young adults. Campaigns for the prevention of falling asleep while driving emphasize this warning sign of the risk of falling asleep involuntarily. Research on accident prevention is leading to the development of programs for the automatic detection of yawning and blinking by the driver in order to trigger an alarm that forces the driver to stop [21]. Drowsiness can be assessed by establishing an Epworth Score, in order to uncover a syndrome of sleep apnea or other cause of hypersomnia. In children, drowsiness is often manifested by excessive agitation, punctuated by yawning, with an attention-fixing deficit. Before invoking the diagnosis of a possibly hyperactive child, it is advisable to eliminate any sleep apnea syndrome caused by an obstructive hypertrophy of the tonsils or adenoids. Evans [22] describes, in the same spirit, 2 cases of inhalation of foreign bodies into the bronchi, which manifested as suffocation alternating with yawning in succession.

Dyspepsia, or the sensation of a full stomach and slow digestion, and an irritable colon are often associated with salvos of yawns. Considering the importance of the autonomic nervous system, particularly the parasympathetic 
system, in the regulation of digestive functions, it is not surprising that yawning appears to be associated with problems that are essentially functional. The term 'gut brain' or digestive neurology has been used in this context in order to avoid restricting the pathophysiology of this system to motor deficits and to also take into account the sensitivity of the digestive system (visceroception, a component of interoception) $[23,24]$. The discovery of hypocretin, a neuromediator that triggers sensations of hunger and arousal, could also provide an explanation [25]. It is possible that leptin, the messenger of satiety, and ghrelin, another messenger signaling hunger, play roles that have not yet been elucidated [26]. These functional digestive disorders should be seen in light of a vasovagal episode. The circumstances under which it is triggered are multiple: violent emotion, intense pain, the sight of blood, staying in a confined and overheated space, etc. The most common form of the malaise, a loss of consciousness, which occurs in subjects of all ages regardless of their state of health, is preceded by a rich parade of premonitory disorders that attest to a hyperstimulation of the parasympathetic system: pallor, nausea, salvos of yawning, visual disturbances, etc. The appearance of yawning is a sign that should attract the attention of a health-care worker during invasive exploration and allow him/her to anticipate a loss of consciousness and subsequent fall. Dorsal decubitus, or an injection of atropine, eliminates the malaise and yawning [27]. Motion sickness, or kinetosis, is a related functional disorder that is often accompanied by repetitive yawning before the onset of vomiting [28]. The beginning of hypoglycemia in a diabetic under insulin therapy is accompanied by a feeling of hunger, profuse sweating and repeated yawning, similar to the feeling of hunger in nondiabetics.

With a progression that is often insidious, an increase in the frequency of yawning becomes embarrassing both because of the brief pause in activity that it causes and because of the negative social connotations perceived by both the yawner and his/her entourage. Often occurring in salvos of 10-20 successive yawns, the daily number often exceeds 100. Thus, the famous patient presented at the 'Leçons du Mardi de la Salpêtrière' on October 23, 1888 by Charcot [29] yawned 8 times a minute, or 480 times an hour! Today, the most frequent cause is of an iatrogenic origin. Numerous medications used in neurology and in psychiatry lead to an increase in the frequency of yawning. We will review them in decreasing order of frequency. Antidepressants, in particular serotonergic antidepressants (SSRIs) are the ones most often found to be involved $[30,31]$. The effect involves the entire phar- macological class, and all molecules studied have been implicated (fluoxetine, paroxetine, escitalopram, duloxetine, venlafaxine, etc.) [32-34]. This symptom is very often wrongly interpreted both by patients and their treatment providers. Attributed to asthenia, the persistence of a depressive state, or a lack of effectiveness of the treatment, frequent repetitive yawning can wrongly lead to an increase in the recommended dosage, which in turn accentuates the problem, whereas stopping the treatment would allow the symptoms to disappear within a few days. There is never any associated somnolence. This effect is sometimes accompanied by erection of the clitoris and involuntary orgasms [35]. SSRIs are nevertheless considered to be better tolerated than tricyclic antidepressants or MAOIs. It is not easy to interpret the somewhat inconsistent mechanism controlling this side effect. In fact, in addition to their activity as serotonergic agonists (5-HT4 receptors?), these molecules also have adrenergic, muscarinic cholinergic and histaminergic effects $[36,37]$. Unfortunately, this is only rarely reported to pharmacovigilance agencies and there are neither statistics to assess the frequency of this iatrogenic effect, nor any studies showing that it is revealed by association with another psychotropic drug [38]. Curiously, while tricyclic antidepressants have atropinic side effects, thus being inhibitors of yawning, and are reputed to lead to impotence, there have been reports regarding excessively frequent salvos of yawning that accompany involuntary orgasms with clomipramine $[39,40]$.

Concerning dopamine agonists, we have already discussed the injection of apomorphine hydrochloride during episodes of motor block in Parkinson's patients in order to restore motricity. It is not possible to invoke a real iatrogenic effect here. Apomorphine hydrochloride, at lower doses administered orally, is used to treat male impotence. Data sheets accompanying the product indicate yawning as a rarely reported side effect seen during the initial clinical studies. Since commercialization, no follow-up data have been accessible. Data for other dopaminergic agonists (bromocriptine, lisuride, pergolide, ropinirole, pramipexole, selegiline and piribedil) are no doubt lacking as a result of faulty pharmacovigilance, since animal models show evidence of the same iatrogenic risks [41, 42].

Detoxication after prolonged use in heavy users of coffee or of opiates is accompanied by the withdrawal syndrome of repetitive yawning over several days [43-49]. The clinical profile of a neonate with a mother who consumes opiates, legal (methadone, morphine) or not until the end of her pregnancy, can be impressive with respira- 
tory irregularities and pauses interspersed with salvos of yawning [50, 51].

Migraines are one of the most common disorders in humans, affecting $10-20 \%$ of the population at least once a year. It appears to be secondary to a combination of environmental and genetic factors. Clinical and pharmacological findings, as well as recent developments in genetics, confirm the hypothesis that a dysfunction in dopaminergic transmission plays a role in the pathophysiology of a migraine attack. Prodromes (changes in mood, yawning, somnolence, food aversion, etc.) may be related to dopaminergic overstimulation. The dopaminergic system also plays a role in the headache phase on the one hand by participating in nociceptive pathways, and on the other by intervening in the regulation of cerebral arterial circulation. Apomorphine induces more yawning in migraineurs than in nonmigraineurs [14, 52-54]. The shimmering blind-spot is a classic sign of a visual aura. However, a large number of migraineurs have noted that repeated yawning in salvos also acts as an aura before an attack [55-57]. More rarely, the attack ends with repeated yawning, accompanied by drowsiness and a postdrome profile [58, 59].

Yawning can be studied from several angles during the course of a stroke. During the occurrence of an attack, ischemic or hemorrhagic, deficits in vigilance occur accompanied by salvos of yawning, whether or not the victim is conscious [60-62]. This could be due to intracranial hypertension consequent to the stroke. In the case of a deep coma (Glasgow Score $=3$ ), the occurrence of repetitive yawning is a sign of herniation - a grave prognostic sign. Apart from this extremely serious evolution, yawning during the course of a stroke indicates damage to the cortical and subcortical circuitry, and to a mechanism of secondary vigilance stimulation controlled by the reticular formation of the brainstem, a mechanism probably common to the yawning that occurs during a partial seizure in temporal lobe epilepsy. During an ischemic attack affecting the territory of the lenticulostriate arteries, damage to the internal capsule and/or the lentiform nucleus leads to complete hemiplegia due to the lesioning of the pyramidal tracts, while the extrapyramidal pathways are spared. In this case, the paralyzed arm can be seen to move during yawning, bringing the hand up to the mouth. The arm drops immediately following the end of the yawn. We have named this syndrome, which is not a synkinesis, 'parakinesia brachialis oscitans'. With regard to its phylogeny, it has been shown that in quadrupeds like the dog and the horse, there is a synchronization of the ventilatory rhythm with that of gait: 1 ventilatory cycle per gait cycle, with concomitant acceleration while running. In humans, bipedalism has led to the loss of this automatic synchronization, retaining only the swing of the arms while walking, but no strict synchrony with ventilation. After a stroke has interrupted cortical control, the subjacent neurological structures retrieve their ancestral functions, which are normally inhibited by the overlying cerebral structures as a result of evolution. During the movement of the diaphragm while yawning, the paralyzed arm receives motor stimulation from the lateral reticular nucleus of the medulla which couples ventilation and locomotion in animals, an extrapyramidal signal that is not inhibited by the ischemic lesion. In 2 stroke profiles, the persistence of yawning and emotional facial expressions signals the dissociation between automatic and voluntary pathways. In the case of a 'locked-in' syndrome caused by an occlusion in the basilar artery territory, there is quadriplegia in association with bilateral facial paralysis. However, physiological yawning continues to occur [63-65]. Similarly, in bilateral anterior opercular syndrome, or Foix-Chavany-Marie syndrome, the muscles of the face, tongue and laryngopharynx are paralyzed during all voluntary acts, including voluntary smiles or grimaces, as well as during language articulation, whereas the expression of emotions, eye blinking, laughing, coughing, swallowing and yawning remain possible. No voluntary imitation of these movements can be carried out. The cause is ischemic, or more rarely post-traumatic, damage to the frontoparietal opercular areas bilaterally $[66,67]$.

Intracranial hypertension, whether related to a stroke, tumor [68-70] or head trauma [71], can be revealed by headaches and by disturbed vigilance associated with salvos of yawns and convulsions. Certain coma scores used in the USA take into account the presence of yawning in these situations [72,73]. Vegetative states of postischemic lesion, or from other origins, also display 'automatic-voluntary dissociation' with the persistence of frequent yawning [74].

Charcot presented a patient in 1888, referred to above, and reported by Gilles de la Tourette in 1890 [75] as suffering from hysteria. Nevertheless, this young woman of 23 years was amenorrheic, epileptic, suffered from a binasal loss of the visual field and yawned 480 times an hour. In reality, she was probably developing a prolactinoma of the hypophysis. I have also personally observed a 39-year-old acromegalic male with prognathism and moderately protruding brows, suffering from persistent asthenia with salvos of almost 200 yawns per day (unpublished). Similarly, Wong et al. [70] reports a case of a mu- 
cocele of the sphenoid sinus compressing the pituitary stalk, which was revealed by the occurrence of yawning repeated every 15 seconds. There are a number of clinical arguments to show that an unexplained excess of yawning could be the result of a hypothalamo-pituitary disorder, the mechanism of action of which could be the oversecretion or inappropriate release of oxytocin or other neuromediators due to compression $[76,77]$.

There has been little interest in the behavioral disturbances that precede or succeed an epileptic seizure by a few minutes or several hours. Nonetheless, these anomalies could provide orienting data that help to localize the anatomical origin of focal seizures. Before, as well as after, a temporal, or sometimes frontal, epileptic seizure, different automatisms such as rubbing the nose with the fingers, yawning or sighing can be observed. As Jackson wrote around 1876 [78]: 'These symptoms do not occur during but after the paroxysm of the seizure; these are movements that are too well coordinated to result from an epileptic discharge; there exists, I think, a double condition: (1) negatively, a loss of control; (2) positively, an augmentation of the activity of the inferior functional center. In any case, the association or the sequence of gestures is very significant'. In accordance with behavioral data, there is a phylogenetic origin to these stereotypical behaviors. They are noticeable during the fetal stage, and continue into the postnatal period and throughout life. Scratching the face, rubbing the nose, yawning and sighing have been described as automatic behaviors that occur before or after absence seizures or focal seizures. They can also be seen in healthy subjects as they awake from sleep. They can be distinguished as being physiological, at waking, or pathological, for example in temporal lobe epilepsy, depending on whether their velocity is harmonious or not, and whether their repetition is brief or prolonged. These behavioral automatisms are related to the activation of the brainstem or the spinal cord, the seat of their motor and integrative centers. The cortex, where the seizure is localized, is not involved. Thus we see the reappearance of ancestral behavioral automatisms that are necessary for survival (such as walking, swimming, mating and other rhythmic activities, to which yawning also belongs) by a liberating ictal cortical disconnection [79-83]. Goldie and Green [84] present 3 observations found from old reports of Gowers (1885) [85], Penfield and Jasper (1954) [86] and Symonds (1950) [87] of children suffering from 'petit mal' seizures, the beginnings of which are signaled by repeated yawning. In addition to the association between temporal lobe epilepsy and yawning, Penfield and Jasper [86] describe di- encephalic epilepsy, a rare type of epilepsy, whose existence has been questioned by some epileptologists. It brings together the brutal stimulation of sympathetic and parasympathetic activity: a feeling of disconnection from the environment without loss of consciousness; a 'vasomotor storm' with flush; profuse sweating; a rapid rise and fall of body temperature, pulse and arterial pressure; lacrimation; salivation; pupillary inequality; and irregularities of the ventilator rhythm. Salvos of yawning and irrepressible hiccupping accompany this spectacular and very unpleasant profile. The cases described reveal the presence of thalamic tumors [88-92]. D’Mello et al. [93] also report salvos of yawns as an iatrogenic effect of vibratory massage or of the withdrawal of neuroleptics, persisting several months after convulsions are provoked. They propose a lesioning of the hypothalamus by way of explanation.

Occurring at the threshold between absence seizures and epilepsy of a psychogenic origin, prolonged hyperventilation (voluntary or unconsciously induced), can alter the level of consciousness, mimicking an epileptic fit, with the appearance of automatic movements such as smiling, swallowing or yawning $[94,95]$. Positive or negative emotions are accompanied physiologically by modifications in cardiorespiratory activity, mediated by the autonomic nervous system. Thus, an increase in the frequency of ventilation is one of the signs of a panic attack. The hyperventilation syndrome comprises a neurotic profile on its own, leading to respiratory alkalosis, accompanied in more than $30 \%$ of cases by repeated widely spaced yawns that could be seen as a homeostatic counterstimulation of the parasympathetic system [96-100]. The use of relaxation techniques and yoga designed to trigger relaxing yawns allows these problems to be treated [101].

In 2006, in a study published exclusively on the internet, Gallezzo [102], of Holyoke Community College (Holyoke, Mass., USA), demonstrated the existence of a link between the frequency of yawning reported by depressive patients and the severity of the depression, using a small sample of 31 patients. Depression was evaluated with the help of the Goldberg Scale, and yawning was evaluated on the basis of a questionnaire proposed by Greco and Baenninger [103]. Statistical analysis of the results demonstrated a significant link: the more the patient yawned, the more severe the depressive state was. This was the first time that such a study was performed. To the surprise of the author, there was a negative correlation between age and yawning. It should be noted that the number of yawns produced diminishes physiologi- 
cally with age, and that the predictive value of the relation between yawning and depression is probably lost after 65 years. It should also be remembered that antidepressants, in particular serotonergic antidepressants, promote repeated yawning.

At present, it is quite rare to encounter a schizophrenic who does not take neuroleptics, which, by their mode of action, inhibit yawning. In the past, the reappearance of yawning in a schizophrenic was interpreted as a resumption of contact with the environment and socialization [104]. Salvos of yawns, such as seen in at least 3 of the 5 cases reported by Gilles de la Tourette in 1890, could have a psychogenic cause as a form of nonverbal language. They have been described as an urgent and irrepressible feeling following a sensation of epigastric heaviness with ascendant retrosternal constriction, relieved by undergoing a ventilatory period of yawning that yields brief pleasure such as that described by patients affected by nervous tics $[105,106]$.

Sandyk [107] has reported a series of 5 patients in the initial stages of Steele-Richardson-Olszewski syndrome, or progressive supranuclear palsy, with balance deficits, oculomotor problems and salvos of repeated yawning that were reduced, paradoxically, by the administration of dopaminergic agonists. Louwerse (1998) [108] reports the existence of excessive yawning in salvos in around $10 \%$ of 200 patients with the bulbar form of amyotrophic lateral sclerosis, or Charcot's disease, which is also the case in the study carried out by Williams [108]. Wicks [109] sees this problem in $47 \%$ of patients in a series of 539. Present during the initial phase of the disease, concurrently with the appearance of swallowing deficits, yawning disappears with the aggravation of paralysis. A brainstem attack in multiple sclerosis can yield the same profile [110].

Between 1917 and 1925, an epidemic of encephalitis, described as lethargic by von Economo [111] (1876-1931), invaded all of Europe. After an initial meningitic phase, a lethargic phase lasting several weeks set in. These acute symptoms, often mortal, were succeeded in those who survived by a 'chaos of abnormal movements' (Pierre Marie), with the combinations of depressive or delirious manifestations, oculogyric crises, Parkinsonian syndromes, etc. In 1921, Sicard and Paraff [112] reported observations in which the initial lethargic phase was followed by spasmodic attacks of hiccupping, laughing or crying, and salvos of repetitive yawning several times a day. The homogeneity of the process of morbidity and the relative consistency of the lesion sites were in contrast to the polymorphism of the clinical manifestations. Con- temporary discoveries confirm the soundness of the hypotheses put forward by von Economo. Autoimmune injury to the basal ganglia of the hypothalamus leads to a rarefaction of orexin/hypocretin-containing neurons, among others, and decreases, either transiently or permanently, the secretion of certain neuromediators responsible for arousal.

At the end of this vast panorama, the consultation of a patient complaining of excessive yawning can be schematized. The first step consists of looking for an iatrogenic effect, the most frequent cause. Then, a search for abnormal drowsiness or sleep debt should allow any syndrome of sleep apnea to be uncovered. Functional causes leading to an anxiety disorder, possibly associated with a hyperventilation syndrome, should be treated by relaxation and yoga. This should be correlated with the occurrence of dyspepsia. Clinical examination is needed to detect pituitary/hypophyseal endocrine anomalies, intracranial hypertensive syndromes, a partial temporal seizure, stroke or Charcot's disease. Finally, repeated yawning could form part of a tic disease.

\section{Acknowledgement}

I am indebted to William House for his corrections and I thank him very much.

\section{References}

1 Walusinski O, Deputte BL: The phylogeny, ethology and nosology of yawning. Rev Neurol (Paris) 2004;160:1011-1021.

2 Barbizet J: Yawning. J Neurol Neurosurg Psychiatry 1958;21:203-209.

-3 Baenninger R, Binkley S, Baenninger M: Field observations of yawning and activity in humans. Physiol Behav 1996;59:421-425.

4 Daquin G, Micallef J, Blin O: Yawning. Sleep Med Rev 2001;5:299-312.

5 Kita I, Yoshida Y, Nishino S: An activation of parvocellular oxytocinergic neurons in the paraventricular nucleus in oxytocin-induced yawning and penile erection. Neurosci Res 2006;4:269-275.

6 Collins GT, Witkin JM, Newman AH, Svensson KA, Grundt P, Cao J, Woods JH: Dopamine agonist-induced yawning in rats: a dopamine D3 receptor-mediated behavior. J Pharmacol Exp Ther 2005;314:310-319.

7 Meige H, Feindel G: Les tics et leur traitement. Paris, Masson, 1902, p 633.

8 Craig AD: Interoception: the sense of the physiological condition of the body. Curr Opin Neurobiol 2003;13:500-505. 
$>9$ Craig AD: How do you feel - now ? The anterior insula and human awareness. Nature Rev Neurosci 2009;10:59-70.

-10 Mogilnicka E, Klimek V: Drugs affecting dopamine neurons and yawning behavior. Pharmacol Biochem Behav 1977;7:303-305.

11 Colosimo C, Pontieri FE: Yawning in Parkinson's disease. Neurology 1999;52:428.

- 12 Collins GT, Newman AH, Grundt P, Rice KC, Husbands SM, Chauvignac C, Chen J, Wang S, Woods JH: Yawning and hypothermia in rats: effects of dopamine D3 and D2 agonists and antagonists. Psychopharmacology (Berl) 2007;193:159-170.

-13 Blin O, Masson G, Azulay JP, Fondarai J, Serratrice G: Apomorphine-induced blinking and yawning in healthy volunteers. Br J Clin Pharmacol 1990;30:769-773.

-14 Blin O, Azulay JP, Masson G, Aubrespy G, Serratrice G: Apomorphine-induced yawning in migraine patients: enhanced responsiveness. Clin Neuropharmacol 1991;14:9195.

15 Goren JL, Friedman JH: Yawning as an aura for an L-Dopa-induced 'on' in Parkinson's disease. Neurology 1998;50:823.

16 Dewey RB, Hutton JT, Lewitt PA, Factor SA: A randomized, double-blind, placebo-controlled trial of subcutaneously injected apomorphine for parkinsonian off-state events. Arch Neurol 2001;58:1385-1392.

$\checkmark 17$ Kolls BJ, Stacy M: Apomorphine: a rapid rescue agent for the management of motor fluctuations in advanced Parkinson disease. Clin Neuropharmacol 2006;29:292-301.

18 Lal S: Apomorphine in the evaluation of dopaminergic function in man. Progr Neuropsychopharmacol Biol Psych 1988;12:117164.

19 Lal S, Tesfaye Y, Thavundayil JX, Skorzewska A, Schwartz G: Effect of time-of-day on yawning response to apomorphine in normal subjects. Neuropsychobiology 2000;41: 178-180.

20 Lewitt PA, Ondo WG, Van Lunen B, Bottini PB: Open-label study assessment of safety and adverse effects of subcutaneous apomorphine injections in treating 'off' episodes in advanced Parkinson disease. Clin Neuropharmacol 2009, Epub ahead of print.

-21 Benoit A, Caplier A: Hypovigilance analysis: open or closed eye or mouth? Blinking or yawning frequency? Advanced Video and Signal Based Surveillance. 2005:207-212.

22 Evans EB: Yawning in pharyngeal obstruction. Br Med J 1978;1:443-444.

23 Cameron OG: Visceral Sensory Neuroscience: Interoception. Oxford, Oxford University Press, 2002.

24 Grover M, Drossman DA: Psychopharmacologic and behavioral treatments for functional gastrointestinal disorders. Gastrointest Endosc Clin N Am 2009;19:151-170.

-25 Sato-Suzuki I, Kita I, Seki Y, et al: Cortical arousal induced by microinjection of orexins into the paraventricular nucleus of the rat. Behav Brain Res 2002;128:169-177.
26 Adamantidis A, de Lecea L: Sleep and metabolism: shared circuits, new connections. Trends Endocrinol Metab 2008;19:362-370.

27 Cronin TG: Yawning: an early manifestation of vasovagal reflex. AJR Am J Roentgenol 1988;150:209.

28 Graybiel A, Knepton J: Sopite syndrome: a sometimes sole manifestation of motion sickness. Aviat Space Environ Med 1976;47: 873-882.

29 Charcot JM: Leçons du mardi à La Salpêtrière. Paris, Lecrosnier \& Babé, 1889.

$\checkmark 30$ Beale MD, Murphree TM: Excessive yawning and SSRI therapy. Int J Neuropsychopharmacol 2000;3:275-276.

31 Gutierrez-Alvarez AM: Do your patients suffer from excessive yawning? Acta Psychiat Scand 2007;115:80-81.

32 Chen CH, Lu ML: Venlafaxine-induced excessive yawning. Prog Neuropsychopharmacol Biol Psychiatry 2009;33:156-157.

33 De Las Cuevas C, Sanz EJ: Duloxetine-induced excessive disturbing and disabling yawning. J Clin Psychopharmacol 2007;27: 106-107.

\$3 Harada KI: Paroxetine-induced excessive yawning. Psychiat Clin Neurosci 2006;60: 260.

35 Modell JG: Repeated observations of yawning, clitoral engorgement, and orgasm associated with fluoxetine administration. J Clin Psychopharmacol 1989;9:63-65.

36 Dourish CT, Cooper SJ: Neural basis of drug induced yawning; in Cooper SJ, Dourish CT (eds): Neurobiology of Stereotyped Behaviour. New York, Clarendon Press, 1990, pp 91-116.

-37 Urba-Holmgren R, Holmgren B, Rodriguez R, Gonzalez RM: Serotoninergic modulation of yawning. Pharmacol Biochem Behav 1979; 11:371-372.

38 Sommet A, Desplas M, Lapeyre-Mestre M Montastruc JL: Drug-induced yawning: a review of the French pharmacovigilance database. Drug Saf 2007;30:327-331.

39 Goldberg RL: Sustained yawning as a side effect of imipramine. Int J Psychiatry Med 1983-84;13:277-280.

40 McLean JD, Forsythe RG, Kapkin IA: Unusual side effects of clomipramine associated with yawning. Can J Psychiatry 1983;28: 569-570.

41 Furukawa T: Yawning behavior for preclinical drug evaluation. Methods Find Exp Clin Pharmacol 1996;18:141-155.

42 Mogilnicka E, Klimek V: Drugs affecting dopamine neurons and yawning behavior. Pharmacol Biochem Behav 1977;7:303-305.

43 Evans SM, Griffiths RR: Caffeine withdrawal: a parametric analysis of caffeine dosing conditions. J Pharmacol Exp Ther 1999;289: 285-294.

44 Freye E, Levy J: Acute abstinence syndrome following abrupt cessation of long-term use of tramadol: a case study. Eur J Pain 2000;4: 307-311.
45 Freye E, Levy J: Constitutive opioid receptor activation: a prerequisite mechanism involved in acute opioid withdrawal. Addict Biol 2005; 10:131-137.

46 Gowing L, Ali R, White J: Buprenorphine for the management of opioid withdrawal. Cochrane Database Syst Rev 2004;4:CDO2025.

47 Hiltunen AJ, Lafolie P, Martel J, Ottosson EC, Boreus LO, Beck O, Borg S, Hjemdahl P: Subjective and objective symptoms in relation to plasma methadone concentration in methadone patients. Psychopharmacology (Berl) 1995;118:122-126.

48 Lane JD, Phillips-Bute BG: Caffeine deprivation affects vigilance performance and mood. Physiol Behav 1998;65:171-175.

49 Phillips-Bute BG, Lane JD: Caffeine withdrawal symptoms following brief caffeine deprivation Physiol Behav 1997;63:35-39.

50 Ostrea EM Jr, Chavez CJ, Strauss ME: A study of factors that influence the severity of neonatal narcotic withdrawal. Addict Dis 1975;2:187-199.

51 Robe LB, Gromisch DS, Iosub S: Symptoms of neonatal ethanol withdrawal. Curr Alcohol 1981;8:485-493.

52 Blau JN: Migraine postdromes: symptoms after attacks. Cephalalgia 1991;11:229-231.

53 Cerbo R, Barbanti P, Buzzi MG, et al: Dopamine hypersensitivity in migraine: role of the apomorphine test. Clin Neuropharmacol 1997;20:36-44.

54 Del Bene E, Poggioni M: Video assessment of yawning induced by sublingual apomorphine in migraine. Headache 1994;34:536538.

55 Jacome DE: Compulsive yawning as migraine premonitory symptom. Cephalalgia 2001;21:623-625.

56 Jacome DE: Primary yawning headache. Cephalalgia 2001;2:697-699.

57 Quintela E, Castillo J, Muñoz P, Pascual J: Premonitory and resolution symptoms in migraine: a prospective study in 100 unselected patients. Cephalalgia 2006;26:10511060.

58 Blau JN, Engel HO: Premonitory and prodromal symptoms in cluster headache. Cephalalgia 1998;18:91-93.

59 Schoonman GG, Evers DJ, Terwindt GM, van Dijk JG, Ferrari MD: The prevalence of premonitory symptoms in migraine: a questionnaire study in 461 patients. Cephalalgia 2006;26:1209-1213.

60 Cattaneo L, Cucurachi L, Chierici E, Pavesi G: Pathological yawning as a presenting symptom of brainstem ischaemia in two patients. J Neurol Neurosurg Psychiatry 2006; 77:98-100.

61 Singer OC, Humpich MC, Lanfermann H, Neumann-Haefelin T: Yawning in acute anterior circulation stroke. J Neurol Neurosurg Psychiatry 2007;78:1253-1254.

62 Walusinski O: Yawning and stroke. Editorial commentaries. J Neurol Neurosurgery Psychiatry 2007;78:1166. 
63 Bauer G, Gerstenbrand F, Hengl W: Involuntary motor phenomena in the locked-in syndrome. J Neurol 1980;223:191-198.

-64 Bauer G, Prugger M, Rumpl E: Stimulus evoked oral automatisms in the locked-in syndrome. Arch Neurol 1982;39:435-436.

-65 Krasnianski M, Gaul C, Neudecker S, Behrmann C, Schlüter A, Winterholler M: Yawning despite trismus in a patient with locked-in syndrome caused by a thrombosed megadolichobasilar artery. Clin Neurol Neurosurg 2003;106:44-46.

66 Billeth R, Jörgler E, Baumhackl U: Bilateral anterior operculum syndrome (in German). Nervenarzt 2000;71:651-654.

-67 Laurent-Vannier A, Fadda G, Laigle P, Dusser A, Leroy-Malherbe V: Syndrome de Foix Chavany Marie d'origine traumatique. Rev Neurol 1999;155:387-390.

68 Arai K, Kita K, Komiyama A, Hirayama K, Saeki N, Nagao K: Progressive dysautonomia in hemangioblastoma in the region of the fourth ventricle (in Japanese). No To Shinkei 1986;38:195-200.

69 Gschwend J: Yawning in a case with transsecting glioma of the pons (in German). Fortschr Neurol Psychiatr Grenzgeb 1977; 45:652-655.

70 Wong KY, Ngan KC, Sin VC, Lau WH: Sphenoidal sinus mucocoele and yawning after radiation treatment for nasopharyngeal carcinoma. Clinical Oncol (R Coll Radiol) 1997; 9:415-417.

71 Jurko MF, Andy OJ: Post-lesion yawning and thalamotomy site. Appl Neurophysiol 1975; 38:73-79.

72 Crosby L, Parsons LC: Clinical neurologic assessment tool: development and testing of an instrument to index neurologic status. Heart Lung 1989;18:121-129.

73 Bateman DE: Neurological assessment of coma. J Neurol Neurosurgery Psychiatry 2001;71:113-117.

74 Manish M, Veenu S: Persistent vegetative state. Neurology 2007;68:1635.

75 Gilles de la Tourette G, Huet E, Guinon G: Contribution à l'étude des bâillements hystériques. Nouvelle Iconographie de la Salpêtrière. Paris, Lecrosnier \& Babé, 1890, pp 97-119.

76 de Wied D: Behavioral pharmacology of neuropeptides related to melanocortins and the neurohypophyseal hormones. Eur J Pharmacol 1999;375:1-11.

-77 Sato F, Aoki H, Nakamura K, Taguchi M, Aoki T, Yasuda N: Suppressive effects of chronic hyperprolactinemia on penile erection and yawning following administration of apomorphine to pituitary-transplanted rats. J Androl 1997;18:21-25.

78 Jackson JH: Selected Writings of John Hughlings Jackson; in Taylor, J (ed): On Epilepsy and Epileptiform Convulsions. London, Basic Books, 1931
79 Medrano V, Selles-Galiana MF, FernandezIzquierdo S, Mallada-Frechin J, Díaz-González F, Piqueras-Rodríguez L: Yawning and temporal lobe epilepsy (in Spanish). Rev Neurol 2005;4:63-64.

80 Muchnik S, Finkielman S, Semeniuk G, de Aguirre MI: Yawning and temporal lobe epilepsy (in Spanish). Medicina (B Aires) 2003; 63:137-139.

81 Muchnik S, Finkielman S, Semeniuk G, de Aguirre MI: Yawning (in Spanish). Medicina (B Aires) 2003;63:229-232.

82 Tassinari CA, Gardella E, Meletti S, et al: The neuro-ethological interpretation of motor behaviours in 'nocturnal-hyperkinetic-frontalseizures': emergence of 'innate' motor behaviours and role of central pattern generators; in Beaumanoir A, Andermann F, Chauvel P, et al (eds): Frontal Seizures and Epilepsies in Children. Montrouge, Libbey Eurotext, 2003, pp 43-48.

83 Yankovsky AE, Andermann F, Dubeau F: Post-ictal forceful yawning in a patient with nondominant hemisphere epilepsy. Epileptic Disord 2006;8:65-69.

84 Goldie L, Green JM: Yawning and epilepsy. J Psychosomatic Res 1961;5:263-268.

85 Gowers WR: Epilepsy and Other Chronic Convulsive Diseases: Their Causes, Symptoms and Treatment. New York, Willam Wood and Co., 1885.

86 Penfield W, Jasper H: Epilepsy and the Functional Anatomy of the Human Brain. Boston, Little, Brown \& Co., 1954.

87 Symonds CP: Discussion on faints and fits. Proc Royal Soc Med 1950;43:507-518.

88 Andy OJ, Jurko M: Diencephalic seizures. Appl Neurophysiol 1983;46:62-67.

89 Boeve BF, Wijdicks EF, Benarroch EE, Schmidt KD: Paroxysmal sympathetic storms ('diencephalic seizures') after severe diffuse axonal head injury. Mayo Clin Proc 1998;73:148-152.

90 Bullard DE: Diencephalic seizures: responsiveness to bromocriptine and morphine. Ann Neurol 1987;21:609-611.

91 Giroud M, Sautreaux JL, Thierry A, Dumas R: Diencephalic epilepsy with congenital suprasellar arachnoid cyst in an infant. Childs Nerv Syst 1988;4:252-254.

92 Goh KY, Conway EJ, Da Rosso RC, Muszynski CA, Epstein FJ: Sympathetic storms in a child with a midbrain glioma: a variant of diencephalic seizures. Pediatr Neurol 1999; 21:742-744.

93 D’Mello DA, Vincent FM, Lerner MP: Yawning as a complication of electroconvulsive therapy and concurrent neuroleptic withdrawal. J Nerv Ment Dis 1988;176:188-189.

94 Lum LM, Connolly MB, Farrell K, Wong PK: Hyperventilation-induced high-amplitude rhythmic slowing with altered awareness: a video-EEG comparison with absence seizures. Epilepsia 2002;43:1372-1378.
95 Lafleur J, Reiher J: Pseudo-absences. Electroencephalogr Clin Neurophysiol 1977;43: 279-280.

$\$ 96$ Bidat E, Sznajder M, Fermanian C, et al: A diagnostic questionnaire for the hyperventilation syndrome in children (in French). Rev Mal Respir 2008;25:829-838.

97 Klein DF: False suffocation alarms, spontaneous panics, and related conditions: an integrative hypothesis. Arch Gen Psychiatry 1993;50:306-317.

98 Nardi AE, Freire RC, Zin WA: Panic disorder and control of breathing. Respir Physiol Neurobiol 2009;167:133-143.

99 Philippot P, Chapelle G, Blairy S: Respiratory feedback in the generation of emotion. Cogn Emot 2002;16:605-627.

100 Saper CB: The central autonomic nervous system: conscious visceral perception and autonomic pattern generation. Annu Rev Neurosci 2002;25:433-469.

101 Brown RP, Gerbarg PL: Sudarshan Kriya Yogic breathing in the treatment of stress, anxiety and depression: part I-neurophysiologic model. J Alternat Complement Med 2005;11:189-201.

102 Gallezzo SR: Examining the connection between yawning and depression 2006 . http://baillement.com/recherche/gallezzo. html.

103 Greco M, Baenninger R: On the context of yawning: when, where and why? Psychol Rec 1993;43:175-183.

104 Beckmann H, Zimmer R: An ethological interpretation of stereotypy induced by environmental stimulus. Arch Psychiatr Nervenkr 1981;230:81-89.

105 Marcus N: Yawning: analytic and therapeutic considerations. Int J Child Psychother 1973;2:406-418.

106 Shilkret H: Psychogenic sneezing and yawning. Psychosom Med 1949;11:127128.

107 Sandyk R: Excessive yawning and progressive supranuclear palsy. Int J Neurosci 1987; 34:123-124.

108 Louwerse E: Forced yawning as a pseudobulbar sign in amyotrophic lateral sclerosis. J Neurosci Res 1998;54suppl:392.

109 Wicks P: Excessive yawning is common in the bulbar-onset form of ALS. Acta Psychiatr Scand 2007;116:76.

110 Postert T, Pöhlau D, Meves S, Nastos I, Przuntek $\mathrm{H}$ : Pathological yawning as a symptom of multiple sclerosis. J Neurol 1996; 243:300-301.

111 von Economo C: Encephalitis Lethargica, Its Sequellae and Treatment. London, Oxford University Press, 1931.

112 Sicard JA, Paraff A: Fou rire syncopal et bâillements au cours de l'encéphalite épidémique. Bull Mém Soc Méd Hôp Paris 1921;45:232. 